\title{
Complexities of local cultural protection in conservation: the case of an Endangered African primate and forest groves protected by social taboos
}

\author{
Lynne R. Baker, Adebowale A. Tanimola and Oluseun S. Olubode
}

\begin{abstract}
Globally, some species and habitats receive protection through local belief systems (e.g. indigenous religions) and informal institutions (e.g. social norms and taboos). Where such systems represent the only form of protection for threatened species or environments, they may be critical to the survival of those taxa and sites. We evaluated the effectiveness of long-standing social taboos protecting the Endangered Sclater's monkey Cercopithecus sclateri and forest groves in a community complex in Nigeria. Across its range (southern Nigeria), Sclater's monkey is effectively protected only through informal institutions. At our study site, we conducted a census of the monkey population; measured the area of sacred groves; and compared our findings with estimates from 2010 and 2005, respectively. We observed a $36 \%$ increase in the monkey population (from 249 to 339 individuals) in a core survey area. No groves that we assessed in 2005 had been fully cleared. Although we observed a decline in tree cover for several sacred forests, most groves used regularly by monkeys had changed little. The social taboos related to monkeys and sacred groves remain largely intact; however, other factors threaten the monkey population and remaining forests in this community complex, including the removal of tree patches to accommodate the construction of large residential buildings and the demand for cropland, as well as increased dumping of waste in forested sites. This study highlights the conservation importance and limitations of local cultural protection, as well as the challenges presented when such protection conflicts with community-perceived development needs.
\end{abstract}

Keywords Biocultural diversity, census, Cercopithecus sclateri, informal institutions, monitoring, Nigeria, sacred, Sclater's monkey

LYNNE R. BAKER (Corresponding author) Department of Natural and Environmental Sciences, American University of Nigeria, Yola, Adamawa State, Nigeria. E-mail lynne.baker@aun.edu.ng, sclateri@yahoo.com

Adebowale A. Tanimola Department of Crop and Soil Sciences, Faculty of Agriculture, University of Port Harcourt, Port Harcourt, Rivers State, Nigeria

Oluseun S. Olubode Department of Crop Protection and Environmental Biology, University of Ibadan, Ibadan, Oyo State, Nigeria

Received 3 April 2017. Revision requested 22 June 2017.

Accepted 25 July 2017. First published online 27 November 2017.

\section{Introduction}

Tocal belief systems, such as indigenous religions, and in1 formal institutions, such as social norms and taboos, have been credited with helping to conserve animal species worldwide (e.g. McDonald, 1977; Colding \& Folke, 1997; Deb \& Malhotra, 2001; Lingard et al., 2003; Jones et al., 2008; Kideghesho, 2008; Rabearivony et al., 2008; Sheppard et al., 2010). Taboos may protect certain species because of the role of those species in a society's folklore or myths. Folklore may promote respect for species, such as animals believed to have formerly been human beings (Loudon et al., 2006; Sousa et al., 2014), or it may promote avoidance of species for other reasons, such as if they are considered to be unclean (Lingard et al., 2003).

Some species are protected as sacred because of their connection to religious beliefs. The Hindu-based protection of monkeys (Southwick \& Siddiqi, 1998; Carter \& Carter, 1999 ) is one such example. In African religions, various species are protected because of their association with local deities or spirits (Falconer, 1999; Saj et al., 2006; Baker et al., 2009), and some sacred animals also serve as totems (Olupona, 1993; Getui, 1999; Kideghesho, 2008). Totem animals are those that serve as a symbol or emblem for a social group and have a special affiliation with that group (Stein \& Stein, 2017).

As with animal species, natural sites may have sacred status and receive protection from local or indigenous communities. In many parts of the world, community-based institutions have long regulated or limited access to, and the use of, sacred groves, or forest patches that have religious or cultural significance (Baker, 2017). Such forests may be protected as the abode of a local deity or the resting place of ancestral spirits; they may also receive protection as sites for rituals, ceremonies or worship, or for their part in local folklore. Sacred forests may be ecologically significant, particularly outside protected areas and across anthropogenic (e.g. agricultural) landscapes, where these forests are important for the conservation of biodiversity (Bhagwat \& Rutte, 2006). Within Africa, sacred groves, even some that are small or historically disturbed, may support rare or endemic plant and animal species and thus have high conservation value (e.g. Ghana, Decher, 1997; Tanzania, Mgumia \& Oba, 2003; Sierra Leone, Lebbie \& Guries, 2008).

Where local beliefs or informal institutions represent the only form of protection for threatened species or habitats, 
these religious and cultural systems are crucial to the conservation of those taxa and sites. However, the effectiveness or persistence of such systems can change over time in response to political, socio-economic or religious change. For example, changes in social and economic conditions (e.g. rapidly growing demand for farmland) and land ownership patterns (e.g. shifts in customary land rights or management) threaten local systems of protection for sacred forests (Bhagwat \& Rutte, 2006; Ormsby \& Bhagwat, 2010). The replacement of indigenous religions with Christianity has often been cited as resulting in the erosion or loss of local religious beliefs and practices that promote environmental protection (e.g. Anoliefo et al., 2003; Fowler, 2003). Loss of natural habitat and food sources can also lead culturally protected animal species to increase crop-raiding activities, which in turn can tarnish public opinion of these species (Southwick \& Siddiqi, 1998; Baker et al., 2014a).

One such species is Sclater's monkey Cercopithecus sclateri, one of just two endemic primates in the West African nation of Nigeria. Categorized as Endangered on the IUCN Red List (Baker et al., in press), this species occurs in fragmented populations in southern Nigeria (Baker \& Olubode, 2008) and faces numerous threats, particularly habitat loss and degradation, driven by human population growth and development. Globally, Nigeria is predicted to be the third most populous country by 2050 , when its population will surpass 410 million (UN, 2017). Some of the country's most densely populated areas are in the southern region, where Sclater's monkey occurs.

Across its geographical range, Sclater's monkey does not occur in any official protected areas, such as wildlife sanctuaries or national parks. In the Igbo-speaking region of southern Nigeria, however, two populations are culturally protected by local communities (Akpugoeze community complex in Enugu State and Lagwa-Umunokwu in Imo State) (Oates et al., 1992; Tooze, 1994; Baker et al., 2009). At these sites, monkeys live within the communities and are often seen running on rooftops and across roads, climbing on built structures and collecting fruits from residential compounds. The social taboos against harming and eating monkeys confer a high degree of protection on these populations; consequently they are among the most important populations for conservation of the species. Yet, with changing beliefs, attitudes and conditions, such as increased levels of crop raiding by monkeys and building and road development, the persistence of these populations and their forest habitats is far from assured.

Previous research at these sites found that crop raiding was the primary factor influencing public opinion of these primates (Baker et al., 2014a). Although most residents have negative attitudes towards the monkeys, fear of supernatural retribution and censure by other community members have contributed to the continued adherence to the no-killing taboos. Unlike in Lagwa-Umunokwu, monkeys do not occupy a totemic position in the Akpugoeze community complex (Baker, 2013; Baker et al., 2014a). Such humandimensions investigations are important to understanding social, economic and cultural changes; however, monitoring of the primate populations and forest patches is also essential to tracking the efficacy of the taboos. Ecological monitoring can complement studies of socio-economic and cultural community dynamics.

In Akpugoeze, the first dedicated census of the monkey population was conducted in the mid 1990s (Tooze, 1994). Censuses in both Akpugoeze and Lagwa-Umunokwu were conducted in 2004, 2005-2006 and 2010 (Baker et al., 2009, 2014b). Sacred forest groves (natural habitat patches) were counted and measured in both communities in 2005-2006 (Baker et al., 2009). Although the communities are relatively well vegetated, particularly Akpugoeze, their land is largely cultivated, dominated by oil palm Elaeis guineensis and cassava Manihot esculenta. Sacred groves and other small forested areas are therefore the only remaining natural habitat for monkeys at these sites.

Since the beginning of our research in these communities, we have observed increased encroachment into and loss of forest patches. Akpugoeze and Lagwa-Umunokwu continue to lose individual trees and forest patches as a result of increasing demand for farmland, and road and building development (notably, large houses). The arrival of electricity also reportedly led to the deaths of monkeys at both sites, and monkeys are alleged to have been hunted and killed surreptitiously. We therefore conducted a census of the monkey population in the Akpugoeze community complex, compared our results to estimates from 2010 to assess trends in this population and further evaluated the census technique we developed for these populations. We also measured the area of sacred groves and compared our findings with estimates from 2005 .

Given construction activities, increasingly unfavourable attitudes towards the monkeys and reports of some monkeys being killed clandestinely or by electrocution, we did not expect to find a growing population. We also expected that, compared to a decade previously, sacred groves would be smaller because of increasing pressure on these natural forest patches and changes in customs or practices related to these forests. For example, where chief shrine priests (those who serve the deity of a particular shrine associated with a sacred grove) have died and have not been replaced, we expected groves to show signs of encroachment and degradation.

\section{Study area}

We conducted this research in May 2016 in three politically autonomous Igbo communities (or village groups) that 
comprise the Akpugoeze community complex in Enugu State, southern Nigeria (Fig. 1). The region was formerly one autonomous community. The three communities cover seven villages in total (four villages in one community, two in another, and one in the third community). Protection of Sclater's monkey does not extend throughout the entire community complex (subsequently referred to as 'the community'). Historically, residents of only two villages have adhered strictly to the taboo protecting monkeys, but some residents of the other villages do not eat or harm monkeys. Monkeys are considered to be the property of two deities and also feature in local folklore (Baker, 2013; Baker et al., 2014a). In the two villages where monkeys are strictly protected, monkeys live in close contact with their human neighbours. The primates are commonly observed climbing on buildings, crossing roads (at times busy with vehicular traffic) and eating fruits collected in residential compounds, and as such they are widely considered to be pests (Tooze, 1994; Baker et al., 2014a). Monkeys also regularly use Akpugoeze's sacred groves, small forest patches scattered throughout the community. These forest patches, which are usually surrounded by buildings, farms and oil palm trees, provide habitat and serve as sleeping sites for monkeys (Plate 1). Further details of the study site are available in Baker et al. (2014b).

\section{Methods}

\section{Census}

Given that the Akpugoeze monkey population is relatively conspicuous and habituated to the presence of people, we used a complete count (census) to estimate abundance. Previously we had identified an area of the community where most monkey groups occur because they receive the greatest protection there. This core area $\left(6.5-7 \mathrm{~km}^{2}\right)$ mostly comprises the two villages in which monkeys have traditionally been protected. As we did in 2010, we partitioned the census area into three sectors within the core area. Because monkeys move among the seven villages (although they are found mainly in the core area), the monkey population in the core area is not a closed population. Therefore, we report abundance for the duration of our study only.

Following the methodology of Baker et al. (2014b), we counted the number of (1) social groups, (2) individuals in each group, (3) independent individuals (juveniles and adults) and (4) dependent infants. During an intense survey period (c. 2 weeks), we attempted to repeatedly locate monkey groups in and around areas where they occur regularly, such as sacred groves or stream forests. We checked these sites multiple times during the census period to obtain repeated counts of individual groups. For each group, we recorded minimum reliable counts, or counts of individuals that we could observe clearly (e.g. groups crossing open areas). Even if we suspected a group might be larger (i.e. some individuals were hidden from view), we reported only minimum reliable counts. Thus, we expected our final count would be an underestimate.

As in previous studies, three primary observers (LRB, AAT and OSO) led the census. In 2010 we used four secondary observers, who were residents of villages in the core area; in this study we used six secondary observers, one of whom participated in the 2010 census. Previously, three teams, each consisting of one primary observer and one secondary observer, surveyed each of the three sectors simultaneously (Baker et al., 2014b). We modified this approach slightly in this study. On several days, either two or all three primary observers surveyed one sector with secondary observers. This was done to help resolve counts in areas where several groups were detected, often near one another. Upon seeing monkeys, primary observers attempted to count all individuals in a group; noted group composition, general location, habitat and time; and recorded geographical coordinates using global positioning system (GPS) devices. We used simple maps of the study area to record sightings (time, day, count and location). If observers did not obtain a reliable count of groups, such as when groups fled or hid, we made additional attempts to count these groups.

During surveys, all observers used two-way radios to communicate their position and sightings. Given their lack of experience in counting social primates, secondary observers recorded only the time and location of group sightings. In some cases secondary observers helped flush monkeys from hiding places to facilitate counts.

To determine population change, we calculated the annual rate of increase $(\lambda)$ using the equation $\mathrm{N}_{t}=\mathrm{N}_{\mathrm{o}} \lambda^{t}$, where $\lambda$ is the finite rate of change in a population (Skalski et al., 2005). $\mathrm{N}_{\mathrm{o}}$ is the population count in 2010; $\mathrm{N}_{t}$ is the population count in this study; and $t$ is the number of years between censuses $(t=5.83)$. We used counts of adults and juveniles only, excluding dependent infants to remove annual and seasonal variability in reproduction.

\section{Sacred forest groves}

We measured the area of nine groves, focusing on forests in the core area. We walked slowly along the perimeter of each grove in clear weather and calculated the area using GPS technology. With one exception, we used three GPS units and calculated the mean area. Local informants aided in distinguishing borders, as previous investigations revealed boundary discrepancies and unclear boundaries as a result of connectivity with farm-bush. Along some groves, thick and tall bushy vegetation or crops made it impossible to follow the boundary exactly, even when using a machete. In these cases we were forced to move some distance from the grove's edge. We later used satellite imagery to estimate the overage and deduct it from final area calculations. We 


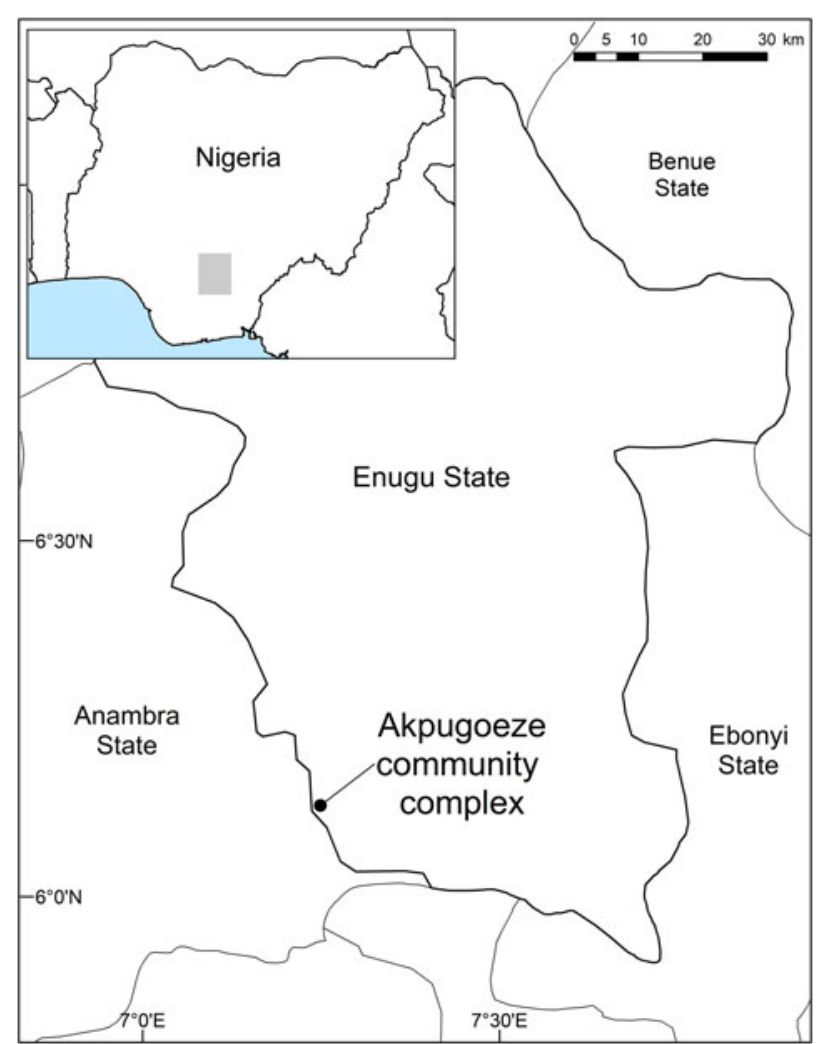

FIg. 1 Location of the Akpugoeze community complex in Enugu State, southern Nigeria. Formerly one politically autonomous community, Akpugoeze now comprises three politically independent communities.

attempted to exclude from grove measurements areas that contained predominantly oil palm trees or that were disturbed (e.g. cut or farmed).

As in 2005 , we did not physically measure one larger grove in the core survey area, to respect the chief priest's wishes (instead we used satellite imagery), nor did we measure protected forest patches along streams, as boundaries were indistinct. Some modifications made in this study meant that we could not compare area measurements directly for all forests assessed in 2005. For example, one continuous forest patch that comprises two sacred groves with distinct customs and histories was previously recorded as two forests. However, given prior misinformation and current lack of clarity regarding boundaries, in this study we measured and recorded this forest patch as a single grove. For seven groves, we compared our findings directly to previous measurements, using a Wilcoxon matched-pair signed-rank test.

\section{Results}

\section{Census}

During the time of our study, we observed an increase in both population size and the number of groups of

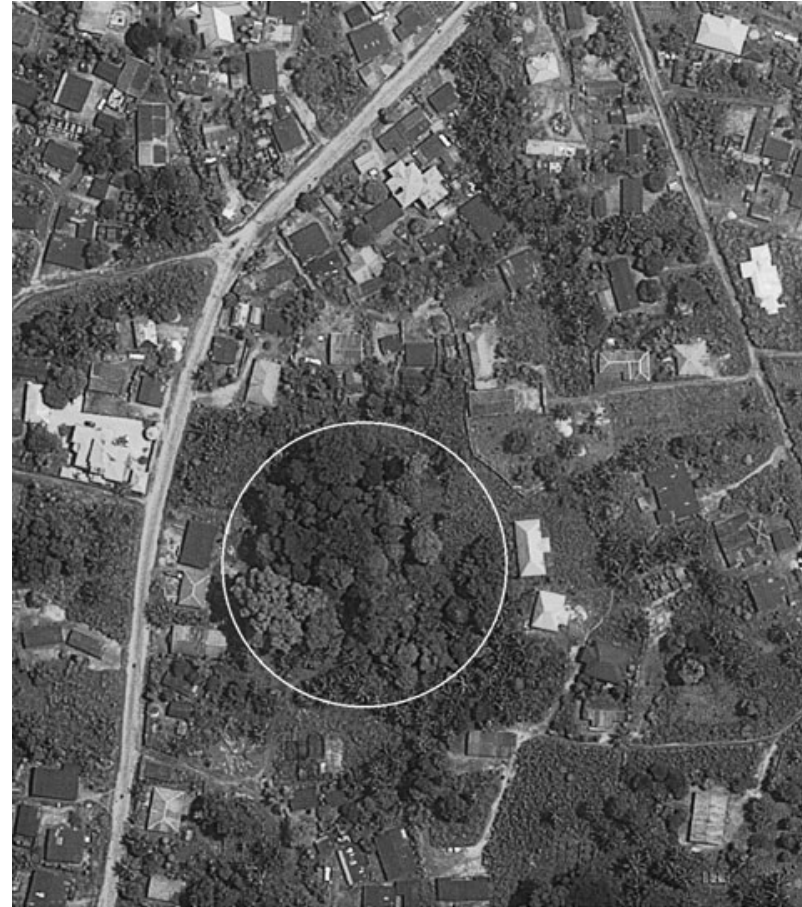

Plate 1 The Agwu sacred forest $\left(7,474 \mathrm{~m}^{2}\right)$, in the Akpugoeze community complex, southern Nigeria (Fig. 1), provides safe habitat for monkeys amidst human habituation and farms.

Sclater's monkeys in the core area of Akpugoeze (Table 1). Our population estimate was the highest to date. We recorded a $36 \%$ increase since the 2010 count (from 249 to 339 individuals), with $\lambda=1.057$. This annual rate of increase was identical to that recorded for the period 2006-2010 (Baker et al., 2014b). We also observed five solitary males, although we omitted these from the overall count.

We estimated there were 25 groups (compared to 18 in 2010) in the core area during the time of our study, although twice we were challenged to resolve group number. In one case, a group divided into two subgroups and joined again more than once. One of these subgroups crossed the main village road at least twice during the survey, from sector to sector. We recorded these subgroups as one group because our count of the larger (possibly ephemeral) grouping was clear (all individuals crossed a wide road). However, this group may have been two social groups that occasionally travelled and fed together. The mean group size was $13.6 \pm$ SD 6.6 individuals (range $=5-32$ ), which was similar to the mean group size in $2010(13.8 \pm$ SD 4.2 individuals, range $=5-24)($ Table 1$)$. The percentage of dependent infants in the population was $9.4 \%$, compared to $10.8 \%$ in 2010 .

As in earlier surveys, we detected Sclater's monkeys in forest patches outside the core area, this time at three sites. These were among the wariest groups we observed. The skittish behaviour of groups occurring closer to the perimeter of the community was anticipated because the degree of persecution by people increases as one moves away from 


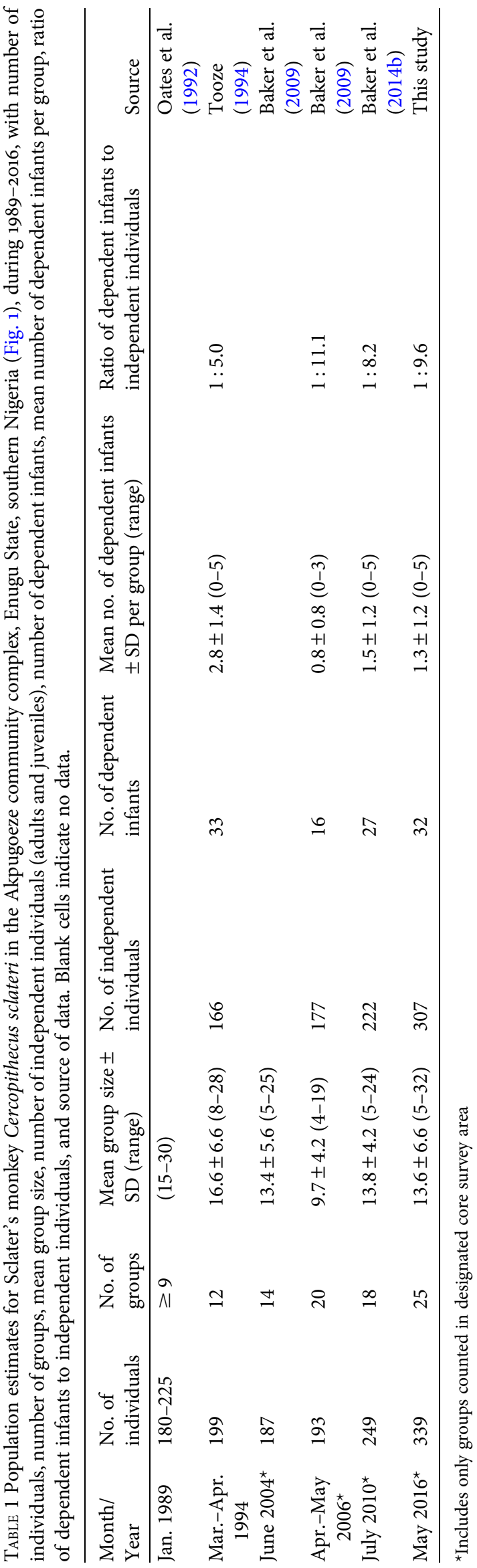

the core area. As in previous censuses, however, some monkey groups in the core area were anxious and behaved as hunted primates (e.g. made alarm calls, hid or fled). During this study we noted increased wariness among much of the Akpugoeze monkey population. This behaviour hindered our ability to count individuals in groups reliably, as some groups would flee immediately upon seeing strangers or when we stopped to observe them.

\section{Sacred forest groves}

No groves that we assessed in 2005 in Akpugoeze had been cleared completely, although a small patch of trees that served as an entrance to a larger sacred forest was converted to an oil palm grove (also see the Postscript). In this study, forest groves that we assessed in the core area were 0.26-9.51 ha (mean $=2.47 \pm$ SD 2.82, $\mathrm{n}=10$ ).

Although we observed a decline in the size of Akpugoeze's sacred forests, our findings were similar to results from 2005. For the seven groves we could compare directly, the difference between the median grove size in 2005 (1.67 ha) and in 2016 (1.48 ha) was not significant $(Z=-1.69$, exact $\mathrm{P}=0.055$, one-tailed). Two groves were slightly larger in 2016 (Fig. 2), which may be attributable to the growth of vegetation resulting from recent rains.

Combining physical measurements, visual inspection and inspection of satellite imagery, we concluded that many forest patches appeared to have been largely unchanged since 2005. However, we noted increased farming and construction activity within the community and around the groves, and we observed people collecting firewood from one protected forest. Previously we recorded African pied hornbills Tockus fasciatus, grey parrots Psittacus erithacus and white-crested hornbills Tropicranus albocristatus in the groves; however, we did not observe the latter two species in this study (nor have we observed these species in the past few years during other visits to this site).

Some forests without chief shrine priests showed signs of tree loss and degradation, but others did not. In Akpugoeze, two shrine forests are considered to be the homes of the two deities that confer protection on the monkeys. In 2005, informants reported that the priest of one of the two shrines (Aki) had died several years previously; by 2016 there was still no priest for this shrine. However, we did not observe any discernible change in forest cover for Aki (but see the Postscript). Similarly, the chief priest of the main shrine forest located in the centre of the community died in late 2011, and a new chief priest did not take over until early 2016. We found that this forest patch was also mostly unchanged since our previous study.

We did observe notable forest clearance and degradation in other areas in the community. Other forest patches with no cultural protection are under pressure. We recorded 


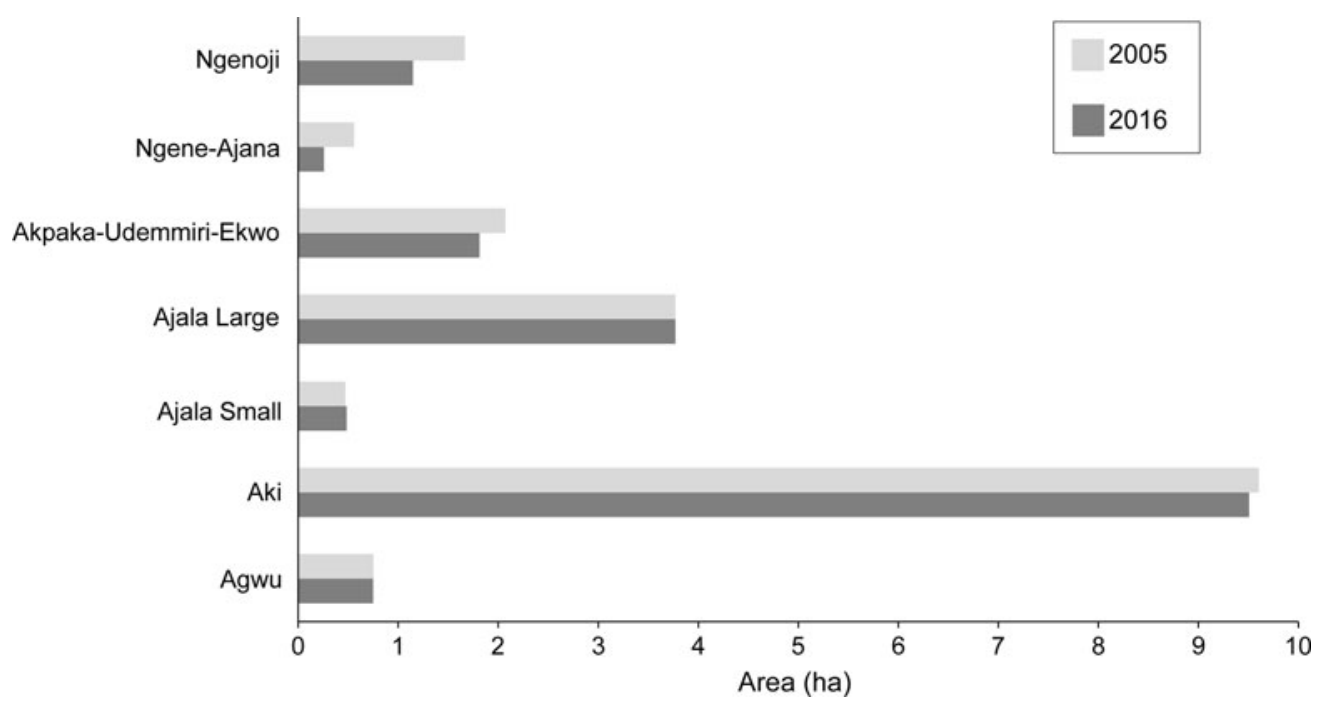

FIG. 2 Change in area of seven sacred groves in the Akpugoeze community complex, southern Nigeria (Fig. 1), between 2005 and 2016.

several new, often large, residential homes (Plate 2) and farm plots where trees had stood. The installation of electrical poles and wires also led to the removal of trees. In addition, we observed increasingly large piles of rubbish around the community. Some of these rubbish piles were within sacred groves or underneath trees where monkeys commonly sleep.

\section{Discussion}

We found no evidence of a declining monkey population in the Akpugoeze community complex. In contrast, we recorded a steadily growing population, and our final abundance estimate is likely to be an underestimate because we recorded minimum reliable counts. Furthermore, we did not observe a significant reduction in sacred forests since 2005. Our findings indicate that the informal institutions protecting Sclater's monkey and sacred forests remain intact and effective and that other factors, such as construction activities, surreptitious killing of monkeys and loss of other forest patches, have not hindered detectably the growth of the monkey population.

\section{Population growth}

We report an increase in the Akpugoeze monkey population with some caution, given that the ranging patterns of this population are not well defined, and the population is not closed. Local and seasonal conditions, such as the loss of trees in and around sleeping sites and stream forests, construction activities and shifts in food availability, may influence how monkeys use the core area at various times of the year. We attempted to control for group movement into and out of the core area by conducting our study over a brief period. Longer-term studies of focal groups would help to clarify our understanding of ranging and grouping patterns in this population.

The rate of population increase we observed, although unexpected, was not startling. The Akpugoeze population benefits not only from no-killing taboos, but also from factors that can encourage primate population growth, such as regular access to human foods (Lyles \& Dobson, 1988; Strum, 2010) and few, if any, natural predators. Additionally, previous conservation awareness work in Akpugoeze resulted in a ban on monkey hunting in one autonomous community whose four villages historically did not respect the taboo against killing monkeys. The ban was decreed by the community's traditional ruler, who first stopped eating monkeys himself. Although we have not specifically studied how knowledgeable residents are about the ban or how effective it has been, the ban may have led to population growth or increased movement of groups within and around this part of the community. It may have also resulted in improved detectability (as groups became less skittish and easier to observe).

Because the Akpugoeze population is the largest culturally protected population of Sclater's monkey across the species' range, the observed population growth is reassuring. However, an increasing population in a limited area may result in greater competition within and among monkey groups and increased levels of crop raiding, thus intensifying human-primate conflict.

\section{Census methodology}

Based on local conditions and the conspicuousness of the monkey population, we reaffirmed that complete counts are appropriate for enumerating primates in the Akpugoeze community complex, yet there are challenges. We have previously discussed challenges associated with surveying 


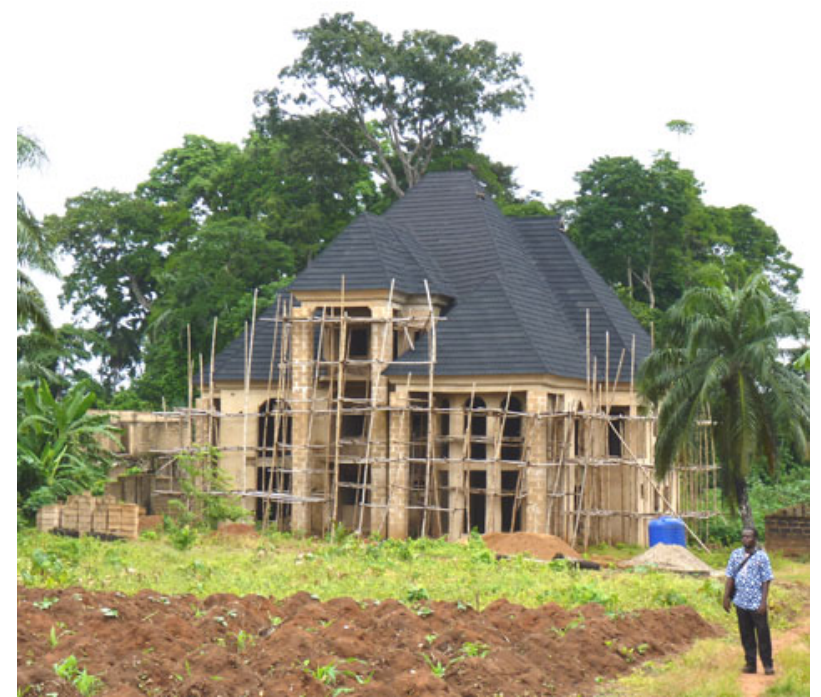

PLATE 2 Construction of a large residence adjacent to a sacred forest grove commonly used by monkeys. (Photograph: Lynne R. Baker)

primates in village, town or city settings (Baker et al., 2014b); for example, even though monkeys are habituated to human presence, they may still be difficult to observe (e.g. hidden behind buildings). Also, monkeys may be wary and flee from observers, as they are chased and harassed by residents, especially when they feed or attempt to feed on human foods.

Unlike in previous censuses, we were also challenged to obtain repeated, reliable counts of groups. Based on former census results, we did not expect to record more than 300 monkeys, and we found that the use of three primary observers and six secondary observers was inadequate to assess a population of this size in a short time period. Although we continue to recommend brief and intense census periods to avoid potential variation in grouping patterns and group movement, we advocate training and employing additional observers, both primary and secondary. A greater number of reliable observers would facilitate counts at sites such as Akpugoeze. Over 5 days, 39 trained assistants conducted a census of a widely dispersed population of 365 whitethighed colobus Colobus vellerosus in Ghana (Kankam \& Sicotte, 2013); c. $75 \%$ of this population is protected by taboos linked to local deities (Saj et al., 2006).

Adding observers can, however, introduce bias in detectability. The three primary observers in this study led the previous three censuses in Akpugoeze; any new primary observers would lack this long-term experience. Even with extensive training and experience, results among observers can vary considerably (Alldredge et al., 2008). For monkey surveys at this site, however, there is no need to distinguish among different species visually or aurally or to measure or estimate sighting distances. This situation reduces potential bias introduced by observer effects. We recommend that more experienced observers initially work alongside newer, less experienced observers to verify counts.

We acknowledge differences in the skill and effort of secondary observers between census periods; only one secondary observer from the previous census participated in this study. Such differences are difficult to control, given the length of time between censuses, availability of competent local assistants, and the willingness of these assistants to participate. As secondary observers did not count individuals in groups, and primary observers actively searched all parts of sectors, sometimes with secondary observers, the probability of overlooking or double-counting groups as a result of variability in skill or effort among secondary observers should be inconsequential.

\section{Conservation implications}

Regardless of social, economic, religious and cultural change in Akpugoeze, taboos protecting the monkeys and sacred groves continue to be effective and thus serve as valuable conservation tools. However, species-focused taboos that do not extend to habitat and critical resources may result in an increasing number of animals in habitats that are decreasing in size and quality (Saj et al., 2006). Taboos may also result in the overcrowding of protected species in marginal habitats or anthropogenic sites, such as villages like Akpugoeze, and may in turn lead to increased incidence of disease, injuries from fighting and depressed reproduction (Southwick et al., 2005). Hunting and eating taboos conferred on locally common or abundant species can exacerbate human-wildlife conflict, with negative effects on livelihoods (Southwick et al., 2005; Srivastava \& Begum, 2005).

Changes within Akpugoeze may have already contributed to the unusual behaviours we observed in the monkey population, notably increased wariness and intergroup fighting. Such behaviours may be partly or wholly a result of increasing disturbance in the community, including the building of cable and wire infrastructure, which reportedly led to the deaths of monkeys once electricity began to flow; removal of non-sacred tree patches in and around monkeys' sleeping sites, especially to accommodate the construction of large residential buildings; and the clearing of trees along stream forests for farmland. Increased harassment of crop-raiding monkeys by residents may also be a factor. As Akpugoeze's sacred groves alone cannot sustain the community's monkey population, other forested sites and natural food sources in the community should be conserved. This is key to addressing crop- and garden-raiding activities by monkeys.

Conservation efforts in Akpugoeze must also address enthusiasm for local development priorities, such as electrical infrastructure, road expansion and the construction of large houses. In Nigeria's Igbo-speaking region it has long been 
customary for more affluent city-dwellers to construct large, modern homes in their ancestral villages, even if they visit only once each year (Uduku, 1996). As the construction of homes and other buildings has led to the clearance of forest patches used by monkeys, conservation efforts should encourage the siting of new buildings in locations that will have little or no impact on the monkeys or remaining tree patches. This will help preserve forested and other natural lands. The use of local building materials and alternative energy sources (e.g. solar) for new construction should also be encouraged.

That the Sclater's monkey population is increasing in Akpugoeze and the sacred groves remain largely intact are encouraging signs for the conservation of this population, as well as the species (although see Postscript). This protection, however, does not extend to other taxa or forests in the community. In the future, an increasing, village-dwelling monkey population is likely to present potentially severe conservation challenges without simultaneous conservation measures focused on habitat, resources and local livelihoods. We intend to continue to work with the Akpugoeze community to address pressing issues, such as forest loss and waste management. Given the Endangered status of Sclater's monkey, and that the species is regarded as a pest by most residents, we also intend to investigate the monkeys' feeding habits and crop-raiding behaviour, including impacts on livelihoods, as well as the monkeys' health and potential for disease transmission.

\section{Postscript}

During a visit to Akpugoeze in May 2017, immediately following a conservation workshop with community stakeholders, LRB learned that a significant part of a large sacred forest (Aki, considered to be the home of one of the two deities that 'owns' the monkeys) was cleared and farmed in early 2017. This was done without the knowledge of community leaders. The clearance of this forest reflects the intense demand for land in south-eastern Nigeria, driven by rapid population growth and eroding respect for the local belief system that had protected the Aki forest for generations. However, the conservation workshop held with stakeholders from Akpugoeze led to unanimous and keen support for conservation and sustainable development in the community. After being made aware of the loss of the Aki forest, community leaders expressed concern, and we have begun discussing more urgent measures for forest protection in the community.

\section{Acknowledgements}

This study was funded by Primate Conservation Inc. We are grateful to the people and leaders of Akpugoeze-
Agbada Autonomous Community, Akpugoeze Autonomous Community and Akpugoeze-Ugwu Autonomous Community, with special thanks to Chief Cyprain Arinze.

\section{Author contributions}

LRB developed the methodology, collected and analysed data and wrote the article. AAT and OSO helped to refine the methodology, collected data and reviewed the manuscript.

\section{References}

Alldredge, M.W., Pacifici, K., Simons, T.R. \& Pollock, K.H. (2008) A novel field evaluation of the effectiveness of distance and independent observer sampling to estimate aural avian detection probabilities. Journal of Applied Ecology, 45, 1349-1356.

Anoliefo, G.O., Isikhuemhen, O.S. \& Ochije, N.R. (2003) Environmental implications of the erosion of cultural taboo practices in Awka-South Local Government Area of Anambra State, Nigeria: 1. Forests, trees, and water resource preservation. Journal of Agricultural and Environmental Ethics, 16, 281-296.

B AKER, L.R. (2013) Links between local folklore and the conservation of Sclater's monkey (Cercopithecus sclateri) in Nigeria. African Primates, 8, 17-24.

B AKER, L.R. (2017) Sacred forests. In The International Encyclopedia of Primatology (ed. A. Fuentes), pp. 1242-1243. John Wiley \& Sons, Oxford, UK.

Baker, L.R., OAtes, J.F., IKemeh, R.A. \& Gadsby, E.L. (in press) Cercopithecus sclateri. In The IUCN Red List of Threatened Species. Http://www.iucnredlist.org.

BAKer, L.R. \& Olubode, O.S. (2008) Correlates with the distribution and abundance of endangered Sclater's monkeys (Cercopithecus sclateri) in southern Nigeria. African Journal of Ecology, 46, 365-373.

Baker, L.R., Olubode, O.S., Tanimola, A.A. \& Garshelis, D.L. (2014a) Role of local culture, religion, and human attitudes in the conservation of sacred populations of a threatened 'pest' species. Biodiversity and Conservation, 23, 1895-1909.

Baker, L.R., Tanimola, A.A., Olubode, O.S. \& Garshelis, D.L. (2009) Distribution and abundance of sacred monkeys in Igboland, southern Nigeria. American Journal of Primatology, 71, 574-586.

Baker, L.R., Tanimola, A.A. \& Olubode, O.S. (2014b) Sacred populations of Cercopithecus sclateri: analysis of apparent population increases from census counts. American Journal of Primatology, 76, 303-312.

Bhagwat, S.A. \& Rutte, C. (2006) Sacred groves: potential for biodiversity management. Frontiers in Ecology and the Environment, 4, 519-524.

Carter, A. \& CArter, C. (1999) Cultural representations of nonhuman primates. In The Nonhuman Primates (eds P. Dolhinow \& A. Fuentes), pp. 270-276. Mayfield Publishing Co., Mountain View, USA.

Colding, J. \& Folke, C. (1997) The relations among threatened species, their protection, and taboos. Conservation Ecology, 1, 6, http://www.consecol.org/vol1/iss1/art6/.

Deb, D. \& Malhotra, K.C. (2001) Conservation ethos in local traditions: the West Bengal heritage. Society and Natural Resources, $14,711-724$. 
Decher, J. (1997) Conservation, small mammals, and the future of sacred groves in West Africa. Biodiversity and Conservation, 6, 1007-1026.

FALCONER, J. (1999) Non-timber forest products in southern Ghana: traditional and cultural forest values. In Cultural and Spiritual Values of Biodiversity (ed. D.A. Posey), pp. 366-370. Intermediate Technology Publications, on behalf of UNEP, London, UK.

Fowler, C.T. (2003) The ecological implications of ancestral religion and reciprocal exchange in a sacred forest in Karendi (Sumba, Indonesia). Worldviews: Global Religions, Culture, and Ecology, 7, 303-329.

Getui, M. (1999) Spiritual beliefs and cultural perceptions of some Kenyan communities. In Cultural and Spiritual Values of Biodiversity (ed. D.A. Posey), pp. 455-457. Intermediate Technology Publications, on behalf of UNEP, London, UK.

Jones, J.P.G., Andriamarovololona, M.M. \& Hockley, N. (2008) The importance of taboos and social norms to conservation in Madagascar. Conservation Biology, 22, 976-986.

Kankam, B.O. \& Sicotte, P. (2013) The effect of forest fragment characteristics on abundance of Colobus vellerosus in the forestsavanna transition zone of Ghana. Folia Primatologica, 84, 74-86.

Kideghesho, J.R. (2008) Co-existence between the traditional societies and wildlife in western Serengeti, Tanzania: its relevancy in contemporary wildlife conservation efforts. Biodiversity and Conservation, 17, 1861-1881.

Lebiie, A. \& Guries, R.P. (2008) The role of sacred groves in biodiversity conservation in Sierra Leone. In African Sacred Groves: Ecological Dynamics and Social Change (eds M.J. Sheridan \& C. Nyamweru), pp. 42-61. James Currey Ltd., Oxford, UK.

Lingard, M., Raharison, N., RabaKonandrianina, E., Rakotoarisoa, J.-A. \& Elmqvist, T. (2003) The role of local taboos in conservation and management of species: the radiated tortoise in southern Madagascar. Conservation and Society, 1, 223-246.

Loudon, J.E., Sauther, M.L., Fish, K.D., Hunter-Ishikawa, M. \& IвRAнім, Y.J. (2006) One reserve, three primates: applying a holistic approach to understand the interconnections among ring-tailed lemurs (Lemur catta), Verreaux's sifaka (Propithecus verreauxi), and humans (Homo sapiens) at Beza Mahafaly Special Reserve, Madagascar. Ecological and Environmental Anthropology, 2, 54-74.

Lyles, A.M. \& Dobson, A.P. (1988) Dynamics of provisioned and unprovisioned primate populations. In Ecology and Behaviour of Food-Enhanced Primate Groups (eds J.E. Fa \& C.H. Southwick), pp. 167-198. Alan R. Liss, New York, USA.

McDonald, D.R. (1977) Food taboos: a primitive environmental protection agency (South America). Anthropos, 72, 734-748.

Mgumia, F.H. \& Ова, G. (2003) Potential role of sacred groves in biodiversity conservation in Tanzania. Environmental Conservation, 30, 259-265.

Oates, J.F., Anadu, P.A., Gadsby, E.L. \& Werre, J.L. (1992) Sclater's guenon-a rare Nigerian monkey threatened by deforestation. National Geographic Research and Exploration, 8, 476-491.

Olupona, J.K. (1993) Some notes on animal symbolism in African religion and culture. Anthropology and Humanism, 18, 3-12.

Ormsiy, A.A. \& Bhagwat, S.A. (2010) Sacred forests of India: a strong tradition of community-based natural resource management. Environmental Conservation, 37, 320-326.

Rabearivony, J., Fanameha, E., Mampiandra, J. \& Thorstrom, R. (2008) Taboos and social contracts: tools for ecosystem management-lessons from the Manambolomaty Lakes Ramsar site, western Madagascar. Madagascar Conservation and Development, 3, 7-16.

Saj, T.L., Mather, C. \& Sicotte, P. (2006) Traditional taboos in biological conservation: the case of Colobus vellerosus at the Boabeng-Fiema Monkey Sanctuary, Central Ghana. Social Science Information, 45, 285-310.

Sheppard, D.J., Moehrenschlager, A., McPherson, J.M. \& MAson, J.J. (2010) Ten years of adaptive community-governed conservation: evaluating biodiversity protection and poverty alleviation in a West African hippopotamus reserve. Environmental Conservation, 37, 270-282.

Skalski, J.R., Ryding, K.E. \& Millspaugh, J.J. (2005) Wildlife Demography: Analysis of Sex, Age, and Count Data. Elsevier Academic Press, Burlington, USA.

Sousa, J., Vicente, L., Gippoliti, S., Casanova, C. \& Sousa, C. (2014) Local knowledge and perceptions of chimpanzees in Cantanhez National Park, Guinea-Bissau. American Journal of Primatology, 76, 122-134.

Southwick, C., Malik, I. \& Siddiqi, M.F. (2005) Rhesus commenalism in India: problems and prospects. In Commensalism and Conflict: The Human-Primate Interface (eds J.D. Paterson \& J. Wallis), pp. 240-257. American Society of Primatologists, Norman, USA.

Southwick, C. \& SidDiQi, M.F. (1998) The rhesus monkey's fall from grace. In The Primate Anthology (eds R.L. Ciochon \& R.A. Nisbett), pp. 211-218. Prentice-Hall, Upper Saddle River, USA.

Srivastava, A. \& Begum, F. (2005) City monkeys (Macaca mulatta): a study of human attitudes. In Commensalism and Conflict: The Human-Primate Interface (eds J.D. Paterson \& J. Wallis), pp. 258-269. American Society of Primatologists, Norman, USA.

Stein, R.L. \& Stein, P.L. (2017) The Anthropology of Religion, Magic, and Witchcraft, 4th edition. Routledge, Abingdon, UK, and New York, USA.

STRUM, S.C. (2010) The development of primate raiding: implications for management and conservation. International Journal of Primatology, 31, 133-156.

Tooze, Z. (1994) Does Sacred Mean Secure? Investigation of a Sacred Population of Sclater's Guenon (Cercopithecus sclateri) in Southeast Nigeria. Unpublished report. Wildlife Conservation Society, New York, USA.

UDUKU, O. (1996) The urban fabric of Igbo architecture in southeastern Nigeria in the 1990s. Habitat International, 20, 191-202.

UN (United Nations) (2017) World Population Prospects: The 2017 Revision, Key Findings and Advance Tables. Working Paper No. ESA/P/WP/248. Population Division, Department of Economic and Social Affairs, United Nations, New York, USA.

\section{Biographical sketches}

LYNNE BAKER's research focuses on human-wildlife interactions, community-based conservation and the conservation of biocultural diversity. Her work on Sclater's monkey in Nigeria began in 2003. ADEBOWALE TANimola researches eco-friendly functions of plant species for the sustainable management of plant-parasitic nematodes to conserve both plant and nematode species. He studies population dynamics and the use of nematodes as bio-indicators of ecosystem perturbations in Nigeria's Niger Delta. Oluseun Olub ode explores the impacts of land use on flora and fauna in natural and artificial environments in Nigeria, to find viable options for protection of species and their habitats. 